\title{
TRAGÉDIA E FILOSOFIA DA HISTÓRIA EM BENJAMIN
}

\author{
THIAGO MotA* \\ ... trágica é a palavra e trágico é o silêncio dos tempos arcaicos...
}

(Walter Benjamin, Origem do drama barroco alemão)

Resumo: Apresentamos uma interpretação da concepção de tragédia no pensamento de Origem do drama barroco alemão (1925), de Walter Benjamin. A partir das críticas dirigidas, de um lado, às abordagens moralizantes do trágico (o aristotelismo moderno na interpretação da tragédia) e, de outro, ao "esteticismo" nietzschiano da metafísica de artista, Benjamin propõe uma concepção do trágico apoiada em uma filosofia da história. Interpretar a tragédia à luz de uma filosofia da história significa buscar o caráter especificamente grego do trágico. Esse elemento trágico consiste, para Benjamin, no agón, no conflito, no caráter agonístico, implicado no silêncio do herói.

Palavras-chave: estética, tragédia, moral, filosofia da história, agón.

\begin{abstract}
We present an interpretation of the conception of tragedy in the thought of The Origins of German Tragic Drama (1925), by Walter Benjamin. Benjamin criticizes the moralizing approaches of the tragic (the modern aristotelism in the interpretation of tragedy) and the nietzschean "aestheticism" of the artist's metaphysics and proposes a conception of the tragic based on a philosophy of history. Interpret the tragedy in the light of a philosophy of history means search for the specific Greek character of the tragic. This tragic element consists, as Benjamin shows, in the agon, the conflict, the agonistic character implicit in the hero's silence.
\end{abstract}

Key-words: aesthetics, tragedy, moral, philosophy of history, agon.

\section{Drama barroco e tragédia. Drama barroco ou tragédia}

Benjamin conclui a primeira parte do capítulo de Origem do drama barroco alemão que trata de drama barroco e tragédia

\footnotetext{
* Doutorando em Filosofia pela Université Catholique de Louvain. Master em Filosofia pela Université de Toulouse II - Le Mirail, pela Université Catholique de Louvain e pela Ruhr-Universität Bochum (Erasmus Mundus Europhilosophie). Mestre em Filosofia pela Universidade Federal do Ceará. Licenciado em Filosofia pela Universidade Estadual do Ceará. Bacharel em Direito pela Universidade Federal do Ceará. Email: thmotafs@gmail.com
} 
com a seguinte afirmação: "a tragédia antiga é uma escrava acorrentada ao carro triunfal do Barroco". ${ }^{1}$ Se o tom dessa passagem soar um tanto agressivo a ouvidos desabituados com a linguagem e o pensamento de Benjamin, pode-se adverti-los de que tal agressividade é, de fato, a intenção do autor. Trata-se, com efeito, de uma "sonora bofetada" na tradição estética e crítica literária que concebeu com descaso o drama barroco como uma tragédia deturpada. Invertendo a ordem dos valores e pondo o drama barroco em uma posição privilegiada frente à tragédia, Benjamin pretende precisamente os contrapor dando cabo à antiga confusão entre Tragödie e Trauerspiel. Interessa a Benjamin definir o drama barroco como uma forma ou idéia autônoma em relação à tragédia, concebendo-o em sua identidade e especificidade, e o primeiro passo para isso é pensar as duas noções como antitéticas. ${ }^{2}$ Portanto, há que ser dito logo de início que o interesse que Benjamin alimenta pela tragédia é de segunda ordem, no sentido de que deriva de sua intenção de definir rigorosamente o drama barroco. Na contraposição entre tragédia e drama barroco é que se pode compreender a concepção benjaminiana do trágico. ${ }^{3}$

A mencionada confusão entre tragédia e drama barroco não deve, no entanto, ser inteiramente tributada à tradição estética e crítica literária. Os autores barrocos não tinham clareza dessa distinção, como se pode perceber na definição de Opitz do drama barroco citada por Benjamin: “"A tragédia é igual em majestade à poesia heróica, com a diferença de que ela realmente tolera a introdução de personagens de baixa extração e de episódios medíocres: seus temas são a vontade dos reis, assassínios, desesperos, infanticídios e parricídios, incêndios, incestos, guerras e

\footnotetext{
${ }^{1}$ BENJAMIN, Walter. Origem do drama barroco alemão. Trad. S. P. Rouanet. São Paulo: Brasiliense, 1984, p. 122.

${ }^{2}$ Bem entendido, a antítese entre drama barroco e tragédia é dialética, uma vez que esta, a exemplo de outros gêneros, como o drama de martírio, o drama de destino etc, estão na origem do drama barroco, que os supera dialeticamente, isto é, conservando em si algo deles. Portanto, a rigor, o barroco não se constitui como forma autônoma antitética à tragédia, pois esta já se encontra, num certo sentido, em sua origem.

${ }^{3}$ Cf. ROUANET, Sérgio P. Apresentação. In: BENJAMIN, Walter. (1984), p. 28.
} 
insurreições, lamentações, gemidos e outros semelhantes"". Dispondo-se a definir o que, para Benjamin, seria o drama barroco, Opitz se refere à tragédia. A definição que ele apresenta, entretanto, não se adequa tão bem a esta quanto ao drama barroco. A influência de Opitz sobre a produção literária do século XVII, por sua vez, comprova a falta de clareza que mesmo os autores barrocos tinham sobre o que criavam. Pensavam eles fazer tragédias quando concebiam dramas barrocos. Eis o drama do drama barroco.

Porém, a definição citada, em sua linguagem barroca, não fomenta apenas a confusão. Para Benjamin, ela tem o mérito de precisar o conteúdo próprio do drama barroco em sua distinção face à tragédia. "Seu conteúdo, seu objeto mais autêntico é a própria vida histórica, como aquela época a concebia. Nisso ele se distingue da tragédia, cujo objeto não é a história, mas o mito, e na qual a estatura trágica das dramatis personae não resulta de sua condição atual, radicada na monarquia absoluta, e sim de uma condição préhistórica, radicada no heroísmo do passado". 5 objeto do drama barroco é a história, em contraposição à tragédia cujo objeto é o mito. Eis a distinção fundamental; as demais derivam de uma forma ou de outra desta distinção.

O drama barroco se enraíza profundamente em seu tempo histórico, é expressão deste. O tempo do drama barroco é o seu presente histórico, isto é, o século XVII e seu contexto sóciopolítico. Somente a partir desse horizonte histórico preciso o drama barroco pode ser compreendido. Não há transcendência possível deste horizonte. Isso é representativo da imanência na história não só do drama barroco, mas de toda obra de arte. Toda obra de arte é imanente a seu tempo e é expressão dele, de modo que não pode ser compreendida se o horizonte histórico em que se insere é suprimido. Assim, a tragédia grega se enraíza na antigüidade clássica tal como o drama barroco se enraíza no século XVII. A interpretação da obra de arte remete, portanto, a uma filosofia da

\footnotetext{
${ }^{4}$ BENJAMIN, Walter (1984), p. 86.

${ }^{5}$ Idem (1984), p. 86.
} 
história. Pode-se dizer que é este o resultado a que chega Benjamin partindo da experiência estética concreta do drama barroco, assim como Nietzsche partindo da experiência estética da tragédia chegara, como foi visto, num certo sentido, a uma metafísica. Mas se a interpretação estética depende de uma filosofia da história, também a tragédia será pensada por Benjamin com base nessa premissa.

A imanência do drama barroco na história, isto é, a história como conteúdo do drama barroco reflete-se no fato de que segundo Benjamin, “os autores acreditavam que a 'tragédia' (Trauerspiel) podia ser captada diretamente no processo histórico: bastava achar as palavras certas". 6 É a história mesma que nesse sentido é trágica, de modo que o autor restringir-se-ia a registrá-la literariamente. Escreve Benjamin que "no século XVII, o termo Trauerspiel se aplicava tanto à obra como aos acontecimentos históricos, do mesmo modo que hoje, com maior justificação, ocorre com o termo trágico". ${ }^{7}$ A confusão entre Tragödie e Trauerspiel estava presente mesmo na linguagem comum. Um evento histórico catastrófico podia ser dito um Trauerspiel, numa formulação em que este Trauerspiel forçosamente teria de ser vertido para o português como "tragédia". ${ }^{8}$ Importa a Benjamin, como foi dito, desfazer esta confusão, definindo rigorosamente Tragödie como tragédia grega antiga e Trauerspiel como drama barroco alemão. Enquanto expressão de seu tempo histórico, a tragédia jamais poderia ser atualizada, não existiria, portanto, uma tragédia moderna ${ }^{9}$, ainda que esta fosse, em sua ingenuidade, a intenção explícita dos autores barrocos. E o mesmo raciocínio valeria para o drama barroco.

\footnotetext{
${ }^{6}$ Idem (1984), p. 87.

${ }^{7}$ Idem (1984), p. 87.

8 A etimologia de Tragödie em alemão, "tragédia" em português, tragoidía ( $\tau \rho \alpha \gamma o l \delta i ́ \alpha)$ em grego, remete a tragos ( $\tau \rho \alpha ́ \gamma o \varsigma)$, bode, donde a tragédia seria um "canto de bode". [Cf. MOISÉS, Massaud. Dicionário de termos literários. 14.ed. São Paulo: Cultrix, 1999, pp. 495 e ss.]. Trauerspiel, por sua vez, é um composto de dois substantivos: Trauer, luto, e Spiel, jogo, portanto, literalmente, "jogo de luto", "jogo lutuoso".

${ }^{9}$ Cf. BENJAMIN, Walter (1984), pp. 124, 136.
} 
Tal análise implica repudiar o descaso da crítica, seja ela desfavorável ou não ${ }^{10}$, em relação ao drama barroco como gênero e como idéia. Benjamin pretende reabilitar o gênero marginalizado do drama barroco, o que somente poderia ser feito, conforme as razões expostas, a partir de um confronto com a tragédia. Trata-se, portanto, de, em consonância com o desiderato da sétima tese Sobre $o$ conceito de história, "escovar a história a contrapelo"," recuperando para o presente a idéia do Barroco. Eis o motivo da bofetada alegórica, apresentada de início, da tragédia como "uma escrava acorrentada ao carro triunfal do Barroco". Trata-se agora de compreender melhor quem é esta "escrava" para Benjamin.

\section{A crítica de Benjamin às abordagens "moralizantes" da tragédia}

Benjamin, assim como Nietzsche, distancia-se das abordagens moralizantes do trágico. "Poderíamos dizer que Benjamin se encontra em continuidade com esta tradição iniciada por Schiller, que perpassa o próprio Nietzsche, e que consiste em procurar se distanciar da idéia de que a tragédia se vinculava, essencialmente, a uma espécie de lição de moral e de virtudes". ${ }^{12}$ Moralizante é precisamente a abordagem que faz da essência da tragédia uma lição de moral. $\mathrm{O}$ espetáculo trágico teria, assim, a função pedagógica de ensinar ao espectador virtudes, bons costumes e uma atitude moralmente correta diante do mundo e da vida. Esta leitura da tragédia, que se tornou hegemônica na tradição

\footnotetext{
${ }^{10}$ No início do século XX, especialmente a partir do fim da I Guerra Mundial, a crítica literária vive um período de reabilitação do barroco, que resulta, em grande parte, do sentimento de afinidade entre a República de Weimar e a época da Guerra dos Trinta Anos (1618-1648). Do ponto de vista de Benjamin, porém, em seu entusiasmo pelo barroco, os críticos literários vão dar continuidade à confusão entre tragédia e drama barroco, o que lhes impede de conceber este como idéia. [Cf. ROUANET, Sérgio P. (1984), pp. 26-7].

${ }^{11}$ BENJAMIN, Walter. Sobre o conceito de história. In: Magia e técnica, arte e política: ensaios sobre literatura e história da cultura. Trad. S. P. Rouanet. 7.ed. São Paulo: Brasiliense, 1994c, p. 225.

${ }^{12}$ CHAVES, Ernani. Idem (2003a), p. 66.
} 
estética e crítica literária desde o século XVIII, baseia-se numa interpretação da Poética de Aristóteles, de modo que pode ser denominada de aristotelismo. $\mathrm{O}$ aristotelismo moralizante do trágico da tradição é visto por Benjamin como fator determinante para a desqualificação do barroco enquanto gênero. No plano do resgate do drama barroco, importa a Benjamin desconstruir esse aristotelismo. Essa desconstrução terá conseqüências inevitáveis sobre a interpretação benjaminiana da própria tragédia.

Em primeiro lugar, importa notar que, para Benjamin, a despeito do reconhecimento da autoridade de Aristóteles pela tradição, a influência aristotélica concreta sobre o drama barroco é totalmente irrelevante. A tradição leu o drama barroco a partir de Aristóteles, todavia, "a história do drama alemão moderno não conhece nenhum período em que os temas da tragédia antiga tenham sido menos influentes. Isso bastaria para refutar a tese da predominância de Aristóteles. Faltava tudo para a compreensão de sua doutrina, principalmente a vontade". 13 Por mais que buscassem se albergar na autoridade de Aristóteles, os autores barrocos não dispunham senão de uma leitura subvertida, voluntariamente, da Poética. ${ }^{14}$ Aquilo que surge como influência aristotélica seria mais justamente tributado a outras fontes, como o classicismo holandês e o teatro jesuítico, verdadeiros precursores do drama barroco. Isso de deve, de acordo com Benjamin, entre outros fatores, ao fato de que “em meados do século XVII a poética aristotélica não era ainda a construção dogmática, simples e imponente, com que se defrontou Lessing". ${ }^{15}$ Ou seja, ao tempo do drama barroco, o aristotelismo ainda não havia se constituído como dogmática, de modo, que se este foi utilizado pela crítica literária posterior ao século XVII para ler o barroco, o foi retroativamente.

\footnotetext{
${ }_{13}^{13}$ BENJAMIN, Walter (1984), p. 84.

${ }^{14}$ Aristotelismo barroco seria, assim, uma leitura subversiva de Aristóteles, como Benjamin sugere na seguinte passagem: "essa 'teoria alheia a seu objeto' impregnou a interpretação da época e permitiu que o novo, através de um gesto aparente de submissão, assegurasse o patrocínio da mais incontestável das autoridades: a do mundo antigo". [BENJAMIN, Walter (1984), p. 122].

${ }^{15}$ Idem (1984), p. 84.
} 
Essa leitura "aristotélica" a posteriori do drama barroco acabou por fomentar a confusão entre este e a tragédia. Daí a crítica que Benjamin objeta à interpretação psicologista da kátharsis

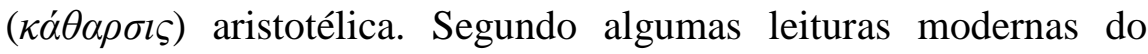
barroco "o drama desse período é uma verdadeira tragédia, porque evoca a 'piedade e o terror'. Ora, essa interpretação psicologista do conceito de catarsis é irrelevante mesmo para a tragédia grega, e o é mais ainda para o drama barroco, que só pode ser explicado a partir da lei de sua forma, e não pelos efeitos produzidos sobre o espectador". ${ }^{16}$ De acordo com a teoria do conhecimento de Benjamin, a obra de arte deve ser interpretada à luz da idéia ou da forma de que é representação, e não com base nos supostos efeitos que ela suscitaria. Isto vale tanto para o drama barroco quanto para a tragédia. Também a interpretação moralista da kátharsis seria inviável. Segundo esta concepção, a kátharsis suscitada pela tragédia teria como função essencial o "aperfeiçoamento moral" do espectador. ${ }^{17}$ Do ponto de vista benjaminiano, esta "função essencial" também não diria nada acerca da idéia, seja do barroco, seja da tragédia, não dando conta, portanto, daquilo que interessa na interpretação da obra de arte.

Isso, todavia, não deve levar a crer que Benjamin prescinda por inteiro da kátharsis aristotélica. Com rigor, seria preciso dizer que a crítica de Benjamin se dirige muito mais ao aristotelismo, isto é, a uma certa leitura moralizante da Poética, do que ao próprio Aristóteles. Nesse sentido, "tanto Nietzsche quanto Benjamin, deixando de lado a Poética e apoiando-se na Política de Aristóteles, consideram que a única possibilidade de kátharsis é aquela proporcionada pelos 'cantos dinâmicos' e 'entusiasmados', que deixam a alma leve e, principalmente, liberta das amarras moralizantes, proporcionando um 'alívio misturado ao prazer' ou ainda uma 'alegria inocente".. ${ }^{18}$ Partindo de uma leitura do sétimo

${ }^{16}$ ROUANET, Sérgio P. (1984), p. 27.

${ }^{17}$ Cf. CHAVES, Ernani. Idem (2003b), p. 197.

${ }^{18}$ Idem (2003b), p. 202. 
capítulo do oitavo livro da Política de Aristóteles, seria possível desvincular a kátharsis do "aperfeiçoamento moral" e ligá-la a uma alegria inocente, isto é, desmoralizada, ou concebê-la de uma perspectiva extra-moral. ${ }^{19}$ Essa ao menos parece ser a referência implícita na seguinte passagem de Origem do drama barroco alemão: “o ’édeos [éleos] aristotélico devia ser compreendido apenas como um impulso ativo para aliviar as angústias e os sofrimentos do próximo, e não como um colapso patológico diante do espetáculo de um destino terrível, como misericórdia, e não como pusillanimitas". ${ }^{20}$

A crítica de Benjamin se volta, portanto, à compreensão de Aristóteles articulada pelos modernos. Esta teria procedido, em primeiro lugar, a uma moralização de Aristóteles e, em seguida, a uma moralização do trágico. A este respeito, escreve Benjamin,

sem qualquer respeito pelos fatos históricos, a filosofia da
tragédia foi construída como uma teoria da ordem ética do
mundo, resultando num sistema de sentimentos, solidamente
apoiados, ao que se julgava, em conceitos como os de "culpa" e
"expiaçãa". (...) os epígonos literários e filosóficos da segunda
metade do século XIX assimilaram, com surpreendente
ingenuidade, aquela ordem ética à ordem causal da natureza, e
em consequêencia o destino trágico foi visto como uma condição
"que se exprime pela interação do indivíduo com um universo
regido por leis".
A leitura moderna da tragédia, concebe o trágico como hýbris ( 'v́ $\beta \rho \imath \varsigma$ ), isto é, como a ruptura efetuada pelo herói da harmonia da ordem universal regida pelas leis olímpicas, leis estas que seriam ao mesmo tempo naturais e éticas. Daí decorre para o herói a "culpa", que há de ser "expiada": este seria o destino trágico. Essa assimilação entre phýsis ( $\varphi v ́ \sigma l \varsigma$ ) e éthos (ćtos) é, todavia, ingênua, pois não está baseada em uma compreensão dos gregos em seu tempo histórico, isto é, falta aos modernos uma filosofia da história. "Na verdade, nada é mais problemático que a competência do 'homem moderno' para julgar, sem qualquer orientação, à luz de seus sentimentos, e mais ainda quando se trata de um julgamento

\footnotetext{
${ }^{19}$ Cf. Idem (2003b), p. 198.

${ }^{20}$ BENJAMIN, Walter (1984), p. 85.

${ }^{21}$ Idem (1984), pp. 123-4.
} 
sobre a tragédia". ${ }^{22}$ A moralização do trágico é tipicamente moderna, baseia-se no julgamento que os modernos, a partir da modernidade, fazem do mundo e quando se dirige aos gregos e, em especial, à tragédia comete inevitáveis anacronismos. Isso se deve, segundo Benjamin, ao fato de que "a filosofia da história foi excluída".23

Da negligência da tradição em relação à filosofia da história deriva o preconceito inquestionado de que "as ações e atitudes dos personagens trágicos podem ser utilizadas para a exposição de problemas morais da mesma forma que um manequim para o ensino da anatomia". ${ }^{24}$ Nesse sentido, na tragédia o homem encontraria um modelo de conduta moral, sobretudo na atitude do herói, no qual deveria pautar seu dia-a-dia. Esse preconceito é o que habilita a interpretação moralizante do trágico a definir, como já foi mencionado, o "aperfeiçoamento moral" como função essencial da tragédia. Escreve Benjamin, "enquanto em outras dimensões os comentadores não se atrevem levianamente a considerar uma obra de arte como uma reprodução exata da vida, na dimensão moral, os comentadores crêem que a obra de arte é uma cópia exemplar, sem se colocarem, sequer, a questão de como fenômenos morais podem ser representados". ${ }^{25} \mathrm{O}$ antigo problema estético da representação, o problema da mímesis ( $\mu i ́ \mu \varepsilon \sigma \iota \varsigma)$ seria, assim, resolvido de antemão no que se trata dos fenômenos morais, ao passo que em outros âmbitos a problemática permaneceria irresoluta. Isto é, existe uma assimetria entre a realidade representada na obra e a realidade em si mesma, porém quanto aos fenômenos morais, a tradição prefere desconhecer essa assimetria, sem fornecer, entretanto, uma solução teórica para esse problema. De fato, para a tradição foi necessário que se passasse por alto o problema, para chegar logo à conclusão de que a obra funciona como uma lição de moral.

\footnotetext{
${ }^{22}$ Idem (1984), p. 124

${ }^{23}$ Idem (1984), p. 125.

${ }^{24}$ Idem (1984), p. 127.

${ }^{25}$ Idem (1984), p. 127.
} 
Todavia, é preciso que fique clara a sutileza da crítica de Benjamin às abordagens moralizantes do trágico, pois para ele não se trata tanto de desqualificar a atribuição de algum conteúdo moral à tragédia (como num certo sentido fizera Nietzsche), quanto de "abrir o caminho para a necessidade de ver no conteúdo moral da poesia trágica, não sua última palavra, mas um momento do seu conteúdo de verdade integral: vale dizer, por meio da história da filosofia". ${ }^{26}$ Desse modo, se Benjamin procede a uma "desmoralização" da tragédia, isto não significa que ele a afaste totalmente da moral. A moral não é a essência do trágico, mas é ainda um de seus momentos de verdade. Não se trata, na desconstrução das abordagens moralizantes da tragédia, para Benjamin, de conceber o trágico de um ponto de vista extra-moral, ou seja, excluindo por completo a moral (e este é um ponto central no confronto de Benjamin com Nietzsche), mas de limpar o terreno para que o momento de verdade moral do trágico venha à luz. E isto só é possível por meio de uma filosofia da história, que é justamente o que falta aos modernos.

Para definir a tragédia como uma lição de moral e o herói como um modelo de conduta moral, a concepção moralizante se baseia no pressuposto infundado e de que ela mesma não chega a ter consciência de que seria possível à arte representar fenômenos morais. Para refutar esse pressuposto basta que se diga, com Benjamin, que "os personagens da ficção só existem na ficção. Como personagens de uma tapeçaria, eles estão de tal forma integrados na tessitura total da obra que não podem de forma alguma ser destacados dela. A figura humana, na literatura, e na arte em geral, tem um estatuto diverso da figura humana real". ${ }^{27}$ Isto é, o contexto em que se dá um fenômeno moral numa obra de arte jamais se confunde com o contexto em que ocorrem os fenômenos morais na vida real. Isso não significa porém, que a moral seja inteiramente desligada da arte. Fenômenos morais estão presentes

\footnotetext{
${ }^{26}$ Idem (1984), p. 128.

${ }^{27}$ Idem (1984), p. 128.
} 
na arte enquanto representados, a arte representa, entre outros elementos, a moral dos homens tal como eles a vivem, ela não veicula uma doutrina moral nem dá lições.

Todo fenômeno moral está ligado à vida em seu sentido extremo, no ponto em que ela se aloja na morte, sede do perigo absoluto. E essa vida, que nos afeta moralmente, isto é, em nossa individualidade única, aparece, ou deveria aparecer, como algo de negativo, do ponto de vista da criação artística. Pois a arte não pode de forma alguma admitir sua transformação em conselheira da consciência moral, dando mais atenção ao sujeito representado que à representação. $\mathrm{O}$ conteúdo de verdade desse todo, que não se encontra nunca na doutrina abstrata, e menos ainda na doutrina moral, mas somente no desdobramento crítico e comentado da própria obra, só inclui referências morais de uma forma altamente mediatizada. ${ }^{28}$

Não é porque a arte não dá conselhos à consciência moral que ela exclui de seu âmbito por completo a moral. A arte representa a moral enquanto fenômeno vital, enquanto vida, na medida em que a moral é um momento de verdade da vida. Nesse sentido, a moral é tema da arte. A moral enquanto representada pela arte não se constitui em doutrina moral, como quis fazer crer a interpretação moralizante. Por não ter uma base histórica, a qual só poderia ser articulada a partir de uma filosofia da história que no entanto está ausente, é que as referências morais acabam por vir à superfície como "objeto principal da investigação". A mediação das referências históricas somente pode ser feita por uma filosofia da história que, todavia, não se encontra entre os modernos.

Da denúncia da exclusão da filosofia da história, elemento central para Benjamin, das modernas abordagens moralizantes do trágico, decorre o imperativo de articular uma investigação apta à compreensão dos gregos em seu próprio tempo, isto é, trata-se de articular a filosofia da história que falta aos modernos. O impulso inicial não só da crítica aos modernos, mas também da necessidade dessa tentativa estaria registrado em $O$ nascimento da tragédia. " este o ponto de Arquimedes que pensadores recentes como Franz Rosenzweig e Georg Lukács encontraram na obra de juventude de

\footnotetext{
${ }^{28}$ Idem (1984), p. 128.

${ }^{29}$ Cf. CHAVES, Ernani (2003a), p. 65.
} 
Nietzsche". ${ }^{30}$ A partir de um confronto crítico com Nietzsche, Benjamin inicia esta tentativa de uma filosofia da história que serve de aporte à compreensão da tragédia em seu caráter especificamente grego.

\section{A crítica de Benjamin ao "esteticismo" de Nietzsche}

Ao fazer a crítica da sensibilidade moderna no que diz respeito ao trágico, Nietzsche teria sido capaz de compreender a tragédia a partir de sua própria época, isto é, ele teria um sentido histórico mais apurado que o da maioria dos modernos. Isso já se reflete "nas intuições de Nietzsche quanto à vinculação da tragédia com a saga, e quanto à independência do trágico em relação ao ethos". ${ }^{31}$ A compreensão do caráter especificamente grego do trágico demanda uma crítica das concepções modernas e uma filosofia da história, cujo primeiro passo seria o esclarecimento da relação entre tragédia e saga. $O$ nascimento da tragédia, de acordo com Benjamin, registra o impulso inicial nesse sentido.

Todavia, se ele parecia encaminhar a investigação num sentido interessante do ponto de vista histórico-filosófico, "o melhor da obra de Nietzsche acabou sendo invalidado por sua metafísica schopenhaueriana e wagneriana". ${ }^{32}$ Isto é, Nietzsche não teria dado continuidade às próprias intuições, devido à influência da metafísica de Schopenhauer e de Wagner em seu pensamento de juventude. Paradoxalmente, "a crítica dirigida ao Nascimento da tragédia no Origem do drama barroco alemão (...) poderia ser resumida com os mesmos termos pelos quais Nietzsche endereçou em diversos textos suas críticas à filosofia ocidental como um todo: "falta de sentido histórico"". 33 Falta-lhe o sentido histórico no tratamento da tragédia porque, apesar de ter intuído a exigência de

\footnotetext{
${ }^{30}$ BENJAMIN, Walter (1984), p. 125.

${ }^{31}$ Idem (1984), p. 125.

${ }^{32}$ Idem (1984), p. 125.

${ }^{33}$ CHAVES, Ernani (2003b), p. 191.
} 
uma filosofia da história, a leitura de Nietzsche acabou por degringolar em uma metafísica do trágico.

Entretanto, esta metafísica do trágico é uma metafísica incomum. Ela parte do interesse de Nietzsche em afastar da tragédia qualquer expediente moralizante. Assim, metafísica e moral foram, pelo primeiro Nietzsche, totalmente desvinculadas. Se existe a proposição de uma metafísica em $O$ nascimento da tragédia, esta é uma metafísica extra-moral, é uma tentativa de dar conta da realidade profunda do mundo e, num certo sentido, de seu fundamento, com base em um olhar que não é moral, mas estético. Pode-se dizer, assim, que a metafísica do trágico é uma tentativa de estetização da metafísica e, por conseguinte, do mundo é uma metafísica estetizante.

Essa tentativa, no entanto, implica perder de vista a filosofia da história. A concepção nietzschiana do mito trágico já apresenta esse problema. Segundo Benjamin, “o mito trágico é para Nietzsche uma construção puramente estética, e a interação de energias apolíneas e dionisíacas, da aparência e da dissolução da aparência, permanece restrita à esfera estética". ${ }^{34} \mathrm{Na}$ medida em que se restringe à esfera da estética, esfera de uma metafísica estetizante, Nietzsche, por um lado, desconstrói a abordagem moralizante do trágico, mas por outro, põe a perder suas intuições acerca da filosofia da história. A pureza estética nietzschiana implica o esvaziamento dos aspectos histórico-filosóficos da investigação acerca do trágico e, ao mesmo tempo, a assunção de uma metafísica. Por sua vez, a concepção de filosofia da história que Benjamin tem em vista, inserida no processo de desconstrução que domina o cenário filosófico do final do século XIX e início do século XX - sobre o qual, não obstante, paira a imagem da "filosofia do martelo" - opõe-se conscientemente à metafísica, em que o jovem Nietzsche acabou incorrendo. Apesar de tê-la intuído, ele renunciou à filosofia da história e "tendo renunciado a um

\footnotetext{
${ }^{34}$ Idem (1984), p. 125
} 
conhecimento histórico-filosófico do mito trágico, Nietzsche pagou um preço alto por seu projeto de emancipar a tragédia dos lugarescomuns morais com que os comentadores a desfiguravam". ${ }^{35} \mathrm{O}$ preço dessa desmoralização do trágico foi a renúncia à filosofia da história em nome de uma metafísica estetizante.

Para Benjamin, o erro de Nietzsche teria sido incorrer em um esteticismo. Essa é, ao menos, a leitura que se encontra em Origem do drama barroco alemão da tese nietzschiana da justificação do mundo como fenômeno estético, elemento central da metafísica do trágico.

"Somente como fenômenos estéticos são o mundo e a existência
justificados para sempre" (...). Abre-se o abismo do esteticismo,
no qual esse intuitivo genial acabou perdendo todos os
conceitos, e assim os deuses e os heróis, o desafio e o
sofrimento, os pilares da construção clássica, evaporam-se num
puro nada. (...) Pois que importa se a obra de arte é inspirada
pela vontade de viver ou pela vontade de destruir a vida, se a
arte, como produto monstruoso da vontade absoluta, se
desvaloriza, desvalorizando o mundo? O niilismo alojado no
cerne da filosofia artística de Bayreuth anulou, e não podia
deixar de anular, a sólida factualidade histórica da tragédia
grega. ${ }^{36}$ Assumindo uma pretensão que não diz respeito à filosofia da história, qual seja, a de justificar o mundo em última instância, a metafísica do trágico, na medida de seu esteticismo, acaba por dissolver a arte no nada. $\mathrm{O}$ esteticismo conduz, assim, a um niilismo em que já não resta nada, nem o mundo que inicialmente se pretendeu justificar. O esteticismo perde de vista, por completo, os fatos, a história, únicos elementos a partir dos quais se poderia articular uma compreensão da tragédia em sua especificidade grega.

Mas não é só isso. $\mathrm{O}$ ataque de Benjamin ao esteticismo, que no livro sobre o barroco se articula através de uma leitura de Nietzsche, é um tema que retorna em obras posteriores. Já sob influência do marxismo, Benjamin desenvolve uma crítica engajada do esteticismo. Em $O$ autor como produtor, acerca do problema da autonomia do autor, isto é, de sua liberdade de criação, lê-se: "a situação contemporânea social o força a decidir a favor de que

\footnotetext{
${ }^{35}$ Idem (1984), pp. 125-6.

${ }^{36}$ Idem (1984), p. 126.
} 
causa colocará sua atividade. O escritor burguês, que produz obras destinadas à diversão, não reconhece essa alternativa. (...) sem o admitir, ele trabalha a serviço de certos interesses de classe". ${ }^{37}$ Ao assumir um esteticismo qualquer, ao defender o lema l'art pour l'art, o artista se crê autônomo e crê ser a sua arte independente, vinculada somente a exigências puramente estéticas. Esse artista não percebe que seu não engajamento, seu caráter supostamente "apolítico" é desde sempre já um posicionamento político. Em política, não há como não se posicionar; o não posicionamento já é um posicionamento. Pensa ele fazer a arte pela arte, enquanto faz arte em função de interesses que não reconhece como tais, mas que nem por isso deixam de ser interesses de uma classe, que é a sua, ainda que ele não tenha propriamente uma consciência de classe. E o interesse dessa classe para se fazer valer se desqualifica como interesse, torna-se sub-reptício. É interesse da classe privilegiada, que se beneficia com a manutenção do status quo, aparecer como “desinteressada" e despolitizar a arte, e não só a arte. A arte pela arte é, assim, a arte em função dos interesses da classe dominante e jamais em função dos interesses da própria arte. Portanto, partindo da pretensão legítima de desconstruir as abordagens moralizantes do trágico, Nietzsche, como que chegando ao extremo oposto, propõe um esteticismo que não deixa de ser burguês, ainda que não tenha consciência disso.

Voltando à Origem do drama barroco alemão, dir-se-ia que o esteticismo de Nietzsche é criticável não somente do ponto de vista político, mas também do ponto de vista da filosofia da história.

\begin{abstract}
A investigação de Nietzsche distanciou-se das teorias da tragédia formuladas pelos epígonos, sem refutá-las. Ele não criticou sua noção central, a doutrina da culpa trágica e da expiação trágica, porque abandonou voluntariamente a tais teorias o campo do debate moral. Tendo negligenciado essa crítica, não pôde ter acesso aos conceitos da filosofia da história e da religião, nos quais tem de se exprimir em última análise qualquer tomada de posição sobre a essência da tragédia. ${ }^{38}$
\end{abstract}

\footnotetext{
37 BENJAMIN, Walter. O autor como produtor. In: Magia e técnica, arte e política: ensaios sobre literatura e história da cultura. Trad. S. P. Rouanet. 7.ed. São Paulo: Brasiliense, 1994b, p. 121.

${ }^{38}$ BENJAMIN, Walter (1984), p. 127.
} 
A crítica de Nietzsche não refuta a moralização do trágico porque perde de vista completamente a moral. Sem ter uma filosofia da história que lhe abrisse esse caminho, Nietzsche deixou de lado o campo de debate moral e acabou não concebendo a moral como tema da tragédia, isto é, não enxergou que a moral está no presente no trágico enquanto representada, ainda que não seja a sua essência. Por outro lado, com uma filosofia da história, de acordo com Benjamin, seria possível ver como a moral se representa no trágico. Mas esta filosofia da história faltou também a Nietzsche.

\section{O trágico e a filosofia da história}

O objetivo central de Origem do drama barroco alemão é a definição rigorosa do que seja o drama barroco para recuperar a idéia do barroco. Um dos terrenos adequados à realização dessa pretensão é o do confronto entre drama barroco e tragédia. A definição rigorosa do drama barroco implica uma definição rigorosa da tragédia, com o que se elimina a confusão entre essas duas idéias. A definição rigorosa da tragédia, como a compreensão da arte de modo geral, pressupõe uma filosofia da história. É preciso compreender o caráter especificamente grego da tragédia para esclarecer o sentido do trágico. Isso significa compreender a tragédia a partir do horizonte histórico grego.

No âmbito desse plano, Benjamin chega a uma tese que rompe com toda uma tradição, a saber, a tese de que não existe tragédia moderna. Aquilo que se convencionou chamar de tragédia moderna é, na verdade, drama barroco: "o teatro moderno não conhece nenhuma tragédia que se assemelhe à dos gregos. Desconhecendo esses fatos, tais teorias dão a entender, presunçosamente, que ainda hoje é possível escrever tragédias". 39 As teorias que propõem o conceito de tragédia moderna partem da premissa de que o trágico teria um potencial de atualização

\footnotetext{
${ }^{39}$ Idem (1984), p. 124
} 
inesgotável, o "pressuposto de que o trágico pode atualizar-se, incondicionalmente, em qualquer configuração factual suscetível de ocorrer na vida cotidiana" 40 , de modo que além da tragédia que se realizou entre os gregos, teria havido tragédias em diversos outros momentos da história e também hoje seria possível escrever tragédias. Assim, no século XVII, teriam sido escritas tragédias, ainda que de segunda categoria, tragédias deturpadas, sob o registro do drama barroco. Do ponto de vista benjaminiano, esse é um pressuposto infundado, pois desconhece um dos aspectos fundamentais da filosofia da história no que diz respeito à arte: o fato de que a obra de arte se enraíza profundamente em seu tempo histórico e é dele expressão. A tragédia grega, enquanto expressão da história grega, não pode ser compreendida fora desse horizonte, de modo que o conceito de tragédia moderna é vazio de sentido.

Só há tragédia antiga (Tragödie); a tragédia moderna é, na verdade, drama barroco (Trauerspiel). Os autores que se referiram à tragédia moderna não tiveram clareza desta distinção. Assim, por exemplo, Schopenhauer, que considerava mais valorosa a tragédia moderna que a antiga. Benjamin escreve conclusivamente que "Schopenhauer percebeu a tragédia como um drama barroco". ${ }^{4}$ Aquilo que o levou a desvalorizar a tragédia dos antigos é precisamente o fato de que os elementos "trágicos", que estariam ausentes ou menos desenvolvidos na tragédia antiga que na moderna, na realidade não pertencem à tragédia, mas ao drama barroco. Franz Rosenzweig, de modo semelhante a Schopenhauer, também percebeu o drama barroco como uma tragédia moderna. Após citar uma longa passagem de A estrela da redenção, Benjamin escreve, "é quase supérfluo observar que a 'tragédia moderna', que essa passagem procura deduzir da antiga, tem um nome significativo: o drama barroco". ${ }^{42}$ Se é feita com rigor a distinção entre drama barroco e tragédia, pode-se chegar não só a uma

\footnotetext{
${ }^{40}$ Idem (1984), p. 124.

${ }^{41}$ Idem (1984), p. 134.

${ }^{42}$ Idem (1984), p. 136.
} 
reavaliação do drama barroco, que deixa de ser tratado como tragédia vulgarizada, mas também a tragédia passa a ser observada a partir dos elementos que lhe são próprios. A obtenção desses elementos se dá, segundo Benjamin, através de uma filosofia da história.

Mas em que consiste o caráter especificamente grego do trágico descortinado pela filosofia da história, isto é, quais são os elementos propriamente trágicos da tragédia? O elemento do trágico é, pode-se dizer com Benjamin, o agón (' $\alpha \gamma \omega ́ v)$. A essência da tragédia está num conflito, cujo caráter é especificamente grego, agonístico.

Onde deve ser procurado esse caráter? Que tendência está contida no trágico? Por que morre o herói? A poesia trágica se baseia na idéia do sacrifício. (...) A morte trágica tem um sentido duplo: anular o velho direito dos deuses olímpicos, e sacrificar o herói, precursor de uma humanidade futura, ao deus desconhecido. Mas esse caráter está presente também no sofrimento trágico (...). Um dos primeiros exemplos é a substituição do sacrifício humano pela fuga da vítima, que escapa da faca ritual, corre em torno do altar, e finalmente o toca (...). Essa profecia agonal distingue-se de todas as obras épico-didáticas. ${ }^{43}$

O conflito que está na essência da tragédia é o que demonstra, portanto, seu caráter agonístico.

Entretanto, em que consiste este conflito agonístico essencial ao trágico? Escreve Benjamin,

Mas com que direito falamos de representação "agonal"? Pois não é suficiente, como justificativa, formular a hipótese de que o enredo trágico deriva da corrida ritual em torno do thymele. É preciso mostrar, em primeiro lugar, que os espetáculos áticos transcorriam sob a forma de uma competição. Não somente os poetas, mas também os protagonistas e os choregas entravam em concorrência. Mas a justificação interna está na angústia muda que cada representação trágica comunica aos espectadores, e se revela nos personagens. No espetáculo, reina a concorrência silenciosa do agon. ${ }^{44}$

A base da poesia trágica é o sacrifício, a morte do herói, seu destino trágico. A morte do herói, decorrente da hýbris, ou seja, de uma infração ao direito olímpico, não restaura simplesmente este direito, mas também engendra um conflito. O direito olímpico é posto em questão na cena trágica diante do público, no conflito que ora se

\footnotetext{
${ }^{43}$ Idem (1984), pp. 129-30.

${ }^{44}$ Idem (1984), p. 130.
} 
instaura entre homens e deuses. A corrida ritual em torno do altar de Dionísio, que é o esquema básico de muitas tragédias ${ }^{45}$, consiste simplesmente em a vítima do sacrifício não aceitar de modo complacente seu destino e fugir da faca sacrificial. Estabelece-se, então, uma competição. Esta competição é a característica fundamental dos espetáculos gregos em todos os seus aspectos. Pois não só os poetas entravam em concorrência nos concursos de poesia, mas também os personagens e os coreutas, e o enredo mesmo da tragédia desenrolava-se sob o signo dessa concorrência. Aqui está uma das contribuições mais fundamentais de Benjamin à investigação acerca da tragédia: a perspectiva do agón é por ele radicalizada de modo a se pensar a própria narrativa trágica como agonística.

Para Benjamin, o caráter agonístico do trágico reflete-se de modo mais evidente no silêncio do herói. Este silêncio trágico é a expressão mesma do agonístico na tragédia. Ao mesmo tempo, a grandeza e a fragilidade do herói são expressas no silêncio. O silêncio é o desafio que o herói lança às leis olímpicas, à ordem cósmica. Através do silêncio é que se trava o agón entre o homem e os deuses, entre o homem e a ordem cósmica que o cerca: eis o sentido do trágico. Todavia, "o silêncio trágico (...) não pode ter apenas o desafio como elemento dominante. Esse desafio se constitui durante a experiência do silêncio, da mesma forma que esta reforça aquele desafio". ${ }^{46} \mathrm{O}$ silêncio trágico é um silêncio desafiante, um desafio que se expressa e se reforça pelo silêncio.

Segundo Benjamin, O nascimento da tragédia deu conta do silêncio trágico. "Uma passagem de Nietzsche demonstra que o fato do silêncio trágico não lhe escapou. Embora ele não tenha se dado conta da significação do fenômeno agonístico na tragédia, esse fenômeno transparece em sua comparação entre a imagem e a

\footnotetext{
${ }^{45}$ Benjamin menciona, a esse respeito, a Oréstia, de Ésquilo. [Cf. Idem (1984), p. 130].

${ }^{46} \operatorname{Idem}(1984)$, p. 131.
} 
palavra". ${ }^{47}$ Para Nietzsche, a imagem supera a palavra, pois esta se aproxima mais do conceito, enquanto a imagem, como a música, se desprende por completo do conceitual para ir ao fundo do real. $\mathrm{O}$ silêncio, na medida em que é só imagem, ausência de palavra, é mais profundo. ${ }^{48}$

Não obstante, a crítica a Nietzsche contida nessa passagem, de que ele não teria dado conta do agón na tragédia, tem de ser interpretada em sua sutileza. Não é verossímil que Benjamin objete a Nietzsche que este não tenha percebido de modo geral o caráter agonístico do trágico, pois tal caráter emerge de forma clara em textos do período de composição de $O$ nascimento da tragédia como A disputa homérica e A filosofia na época trágica dos gregos, conforme foi exposto anteriormente. $\mathrm{O}$ que Benjamin alega é que Nietzsche não captou o agón no interior da trama trágica, como elemento constitutivo da tragédia, nem percebeu o caráter agonístico do silêncio trágico, mas o concebeu, por assim dizer, como um elemento externo. Nesse sentido, Benjamin radicaliza a idéia que já estava em Nietzsche.

A filosofia da história possibilita a compreensão do agón como o caráter especificamente grego da tragédia. Faz-se necessária uma filosofia da história para compreender que, de um modo que escapa totalmente à sensibilidade moderna, na tragédia o agón está imbricado com o silêncio. "Somente as épocas arcaicas podiam conhecer a hubris trágica, que paga com a vida do herói seu direito de permanecer silenciosa". ${ }^{49}$ A hýbris trágica se manifesta no silêncio desafiante do herói ante os deuses. Esse silêncio em que a hýbris se manifesta só faz sentido se for concebido a partir do horizonte da história grega.

Com base em uma filosofia da história é possível compreender "a afinidade profunda entre o processo judicial e a tragédia ateniense. (...) A tragédia assimila a imagem do processo

\footnotetext{
${ }^{47} \operatorname{Idem}(1984)$, p. 131.

${ }^{48}$ Que se pense, por exemplo, no silêncio de Cristo ante o questionamento de Pilatos.

${ }^{49}$ Idem (1984), p. 138.
} 
judicial". ${ }^{50} \mathrm{Na}$ tragédia, tudo ocorre como se se tratasse de um julgamento em que o herói, em razão de seus crimes, de sua desmesura, da hýbris, ocupa o banco dos réus, enquanto os deuses cumprem o papel de juízes. Neste processo trágico "o pugilato, o direito e a tragédia, a grande trindade agonal da vida grega (...) se integram". 51 O agón se estabelece entre o réu e os juízes, na medida em que o herói lança, por meio de seu silêncio, um desafio à ordem olímpica. $\mathrm{O}$ "silêncio do herói, que nem encontra justificação nem a procura, (...) coloca sob suspeita os perseguidores. O sentido desse silêncio se inverte: o que aparece no tribunal não é a culpa do acusado, mas seu sofrimento mudo, e a tragédia, que parece ser um julgamento do herói, transforma-se num julgamento dos deuses". 52 Repentinamente, em razão do silêncio trágico, os papéis se invertem: o herói deixa de ocupar o banco dos réus, que passa a ser ocupado pelos deuses. ${ }^{53} \mathrm{O}$ papel de juiz da contenda, entretanto, passa a ser exercido pelo público da tragédia. Escreve Benjamin, "se no espírito do poeta o mito é um julgamento, sua obra é ao mesmo tempo uma reprodução e uma revisão do processo. E esse processo desenvolveu-se, na íntegra, na dimensão do anfiteatro. A comunidade comparece a essa retomada do processo como uma instância que controla e que julga". ${ }^{4}$ Essa revisão do processo significa que agora a ordem olímpica, o direito antigo é colocado em questão. A justiça eterna é confrontada com o caráter do destino do herói, que ainda encontra forças para, em seu silêncio, confrontar a ordem demoníaca. Através do silêncio do herói, a tragédia rompe o destino demoníaco. Por esta razão, toda poesia trágica contém uma profecia anti-olímpica. Tal resultado somente é obtido através de uma filosofia da história que explicita porque "o decisivo

\footnotetext{
${ }^{50}$ Idem (1984), p. 139.

${ }^{51}$ Idem (1984), p. 138.

${ }^{52}$ Idem (1984), p. 132.

${ }^{53}$ Esta mesma inversão, esta virada da situação em que acusadores e acusados alternam papéis, pode ser encontrada também no primeiro diálogo de Platão, Apologia de Sócrates, cuja estratégia de defesa se articula dessa precisa maneira. [Cf. PLATÃo. Apologia de Sócrates. In: Diálogos. São Paulo: Nova Cultural, 2000.].

${ }^{54}$ Idem (1984), p. 139.
} 
confronto dos gregos com a ordem demoníaca do mundo imprime também na poesia trágica a sua assinatura histórico-filosófica" ${ }^{55} \mathrm{~A}$ tragédia é, nesse sentido, o registro do soçobrar de uma ordem decadente e o anúncio de uma nova ordem.

Finalmente, a partir dessa leitura do trágico baseada em uma filosofia da história, esclarece-se também como a moral surge no seio do trágico. Numa citação de Destino e caráter, texto de 1919, que se encontra em Origem do drama barroco alemão, Benjamin afirma que "não se trata de restaurar a ordem moral do mundo, e sim de uma tentativa por parte do homem moral, ainda mudo, ainda imaturo - por isso ele se chama herói - de se reerguer entre as convulsões de um mundo torturado". ${ }^{56}$ A tragédia, portanto, não deve ser interpretada como o processo no qual se há de restaurar a ordem moral do mundo, isto é, não se trata da redenção da desmesura pela "rearmonização" daquilo que foi tornado desarmônico. Mas há, ainda, um motivo moral, qual seja o do homem moral que tenta se levantar ante a desarmonia que é o modo pelo qual o mundo lhe aparece. A atitude do herói é, em última instância, moral porque é humana. Nesse sentido, a tragédia não veicula nenhuma doutrina moral, nem dá lições, nem é o triunfo de valores mais elevados sobre um homem esmagado. Ela é, ainda, moral porque representa o humano em sua atitude de reerguer-se e fitar de frente a ordem, que já não pode ser mais mantida, do mundo desordenado.

\section{Referências}

ARISTÓTELES. Poética. Trad. E. Souza. 2.ed. São Paulo: Abril Cultural, 1978. Política. Trad. M. G. Kury. 3.ed. Brasília: UnB, 1997.

BENJAMIN, Walter. A obra de arte na era de sua reprodutibilidade técnica. In: Magia e técnica, arte e política: ensaios sobre literatura e história da cultura. Trad. S. P. Rouanet. 7.ed. São Paulo: Brasiliense, 1994a.

\footnotetext{
${ }^{55}$ Idem (1984), p. 132.

${ }^{56}$ Idem (1984), pp. 133-4.
} 
Documentos de cultura, documentos de barbárie: escritos escolhidos. Trad. C. H. M. Sousa et al. São Paulo: Cultrix, EdUSP, 1986.

Gesammelte Schriften. Frankfurt a. Main: Suhrkamp, 1992.

. O autor como produtor. In: Magia e técnica, arte e política: ensaios sobre literatura e história da cultura. Trad. S. P. Rouanet. 7.ed. São Paulo: Brasiliense, 1994b.

Origem do drama barroco alemão. Trad. S. P. Rouanet. São Paulo: Brasiliense, 1984.

Sobre o conceito de história. In: Magia e técnica, arte e politica: ensaios sobre literatura e história da cultura. Trad. S. P. Rouanet. 7.ed. São Paulo: Brasiliense, 1994c.

CHAVES, Ernani. O "silêncio trágico": Walter Benjamin entre Franz Rosenzweig e Friedrich Nietzsche. In: No limiar do moderno: estudos sobre Friedrich Nietzsche e Walter Benjamin. Belém: Paka-Tatu, 2003a.

Kátharsis versus ouvinte estético: sobre a tragédia em Nietzsche e Walter Benjamin. In: No limiar do moderno: estudos sobre Friedrich Nietzsche e Walter Benjamin. Belém: Paka-Tatu, 2003b.

MOISÉS, Massaud. Dicionário de termos literários. 14.ed. São Paulo: Cultrix, 1999.

NIETZSCHE, Friedrich. Kritische Studienausgabe. Berlim/Nova Iorque: Walter de Gruyter, 1980.

O nascimento da tragédia ou helenismo e pessimismo. Trad. J.

Guinsburg. São Paulo: Companhia das Letras, 1992.

ROUANET, Sérgio P. Apresentação. In: BENJAMIN, Walter. Origem do drama barroco alemão. Trad. S. P. Rouanet. São Paulo: Brasiliense, 1984. 